\title{
Dry matter intake, performance and carcass characteristics of hair sheep reared under different grazing systems
}

\author{
Viviane Rodrigues Verdolin dos Santos ${ }^{1}$, Concepta McManus ${ }^{2}$, Vanessa Peripolli ${ }^{3 *}$, Candice Bergmann Tanure ${ }^{1}$, Paulo de Mello \\ Tavares Lima ${ }^{4}$, Patrícia Spoto Corrêa ${ }^{4}$, Daiana Lima Brito ${ }^{1}$, Sônia Emília Figueiredo de Araújo Torres ${ }^{1}$, Helder Louvandini ${ }^{4}$
}

\author{
IUniversity of Brasília/Faculty of Agronomy and Veterinary \\ Medicine - Campus Darcy Ribeiro, SGAN, s/n - 70910-900 \\ - Brasília, DF - Brazil. \\ 2University of Brasília/Biological Sciences Institute - Campus \\ Darcy Ribeiro, SGAN, s/n - 70910-900 - Brasília, DF - \\ Brazil. \\ ${ }^{3}$ Federal Catarinense Institute - Campus Avançado Abelardo \\ Luz, Assentamento José Maria, s/n - 89830-000 - Abelardo \\ Luz, SC - Brazil. \\ 4University of São Paulo/CENA, Av. Centenário, 303 - \\ 13416-000 - Piracicaba, SP - Brazil. \\ *Corresponding author <vanessa.peripolli@hotmail.com>
}

Edited by: Jhones 0. Sarturi/Paulo Cesar Sentelhas

Received July 22, 2016

Accepted October 10, 2016
ABSTRACT: The aim of this study was to evaluate the effect of three different grazing systems: isolated, alternate and simultaneous, on feed intake, performance and carcass characteristics of sheep. About 5.2 ha area of Tanzania grass (Panicum maximun Jacq cultivate Tanzania) was divided into 13 paddocks. This area was used as a stocking rate of two animal units (AU) per ha for 7 days' occupation and 21 days rest. A total number of 58 animals were used consisting of 12 heifers and 30 Santa Ines lambs with the addition of 16 adult ewes that were used to stabilize grazing pressure in the isolated system. The sheep were fed on $200 \mathrm{~g}$ per head per day of concentrate and cattle $2 \mathrm{~kg}$ per head per day. The parameters determined were the following: weekly weight (WW), total live weight gain (LWG) and mean daily weight gain (MDW). Also dry matter intake was estimated 84 days after the start of the experiment using external indicators (Purified and Enriched Lignin) in addition to carcass traits and composition which were also estimated. The result obtained for carcass composition revealed that the muscle:bone ratio and bone percentage were better in the alternate system. Moreover, the simultaneous and isolated systems showed higher lamb performance than the alternate system, while there was no effect on dry matter intake. Furthermore, there was no difference of the different systems on carcass traits and feed intake of sheep. Nevertheless, the simultaneous grazing system showed better sheep performance than the alternate grazing system.

Keywords: carcass quality, carcass weight, simultaneous grazing systems, Tanzania grazing area

\section{Introduction}

In recent years, grazing systems for ruminants have been the subject of sustainability and environmental impact studies (Saggar et al., 2015), as well as ensuring maintenance of animal welfare (Rutter, 2010). In addition, the use of integrated pasture for different herbivorous species leads to beneficial effects on plantanimal interaction (Blanco et al., 2007), increasing the production at pasture, with improved forage quality and efficiency of utilization, with a consequent increase in production per area and per animal.

The selectivity and forage quality requirements for cattle and sheep are different and can be influenced by vegetation composition and diversity (Wrage et al., 2011). Cattle can encircle forage with their tongues with no selectivity for plant quality as they eat to increase bulk in the rumen; however, sheep, on the other hand, have considerable selectivity for high quality plants although they graze with their tongues just like cattle. Whatsmore, they have the ability to eat grasses close to the ground as they have an upper lip fissure which explains why they are called sweeper animals (Rook et al., 2004; Jerrentrup et al., 2015). Thus, complementary grazing of cattle and sheep could be beneficial from an agronomic point of view (Jerrentrup et al., 2015), allowing for better utilization of pastures resulting in a structurally more homogeneous sward (Forbes and Hodgson, 1985).
Carcass and meat quality of sheep are affected by grazing systems mainly in regard to carcass quality and degree of fattening (McClure et al., 1995; Priolo et al., 2002). However, under tropical conditions and with the complexity of existing ecosystems involved, little information on carcass traits as well as the performance of sheep, under different grazing systems is known (Bailey et al., 2009; Dickhoefer et al., 2014). The aim of the present study was to compare the effect of different grazing systems on feed intake, performance, carcass quality and composition of sheep.

\section{Materials and Methods}

Animal care procedures used in this study were the following protocols approved by the ethical committee for animal use at the University of Brasilia under the number 44568/2009.

This experiment was carried out in the Federal District, Brazil, at $15^{\circ} 57^{\prime} \mathrm{S}$ and $47^{\circ} 56^{\prime} \mathrm{W}$, with altitudes ranging from 1050 to $1250 \mathrm{~m}$. At this location the climate is tropical seasonal, according to the Koppen classification (Alvares et al., 2013). Moreover, a 5.2 ha area of Tanzania grass (Panicum maximun Jacq. cultivate Tanzania) was used for this study during the rainy season (Jan to Apr) for 7 days occupation and 21 days rest by dividing it into thirteen paddocks. The thirteen paddocks were then sub-divided into three groups: the first, denominated as "isolated" comprised 4 paddocks with sheep only, 
the second denominated as "alternate", comprised 5 paddocks with sheep grazing after cattle and the last, denominated as "simultaneous" comprised 4 paddocks with cattle and sheep grazing together. A total number of 58 animals were used which were divided into twelve crossbred heifers (six for the isolated and six for the simultaneous), weighing initially $206.70+20.79 \mathrm{~kg}$ and 30 Santa Ines lambs weighing $22.70+2.23 \mathrm{~kg}$, in addition to 16 adult ewes weighing $47.38+7.67$ which were used for stabilizing grazing pressure in the isolated system. The cattle remained inside the paddocks all the time, while the sheep were gathered into shelters every night. The sheep were fed on $200 \mathrm{~g}$ per head per day of concentrate and cattle $2 \mathrm{~kg}$ per head per day. For the sheep, the concentrate mixture consisted of $550 \mathrm{~g}$ $\mathrm{kg}^{-1}$ corn, $300 \mathrm{~g} \mathrm{~kg}^{-1}$ soya bean meal, $100 \mathrm{~g} \mathrm{~kg}^{-1}$ cotton meal and $50 \mathrm{~g} \mathrm{~kg}^{-1}$ wheat meal, with $880 \mathrm{~g} \mathrm{~kg}^{-1}$ dry matter (DM), $220 \mathrm{~g} \mathrm{~kg}^{-1}$ crude protein (CP), 720 $\mathrm{g} \mathrm{kg}^{-1}$ total digestible nutrients (TDN) and $2.613 \mathrm{Mcal}$ $\mathrm{kg}^{-1}$ of metabolizable energy (ME). For the cattle, the concentrate mixture consisted of $600 \mathrm{~g} \mathrm{~kg}^{-1}$ corn and $400 \mathrm{~g} \mathrm{~kg}^{-1}$ soya bean meal, with $880 \mathrm{~g} \mathrm{~kg}^{-1} \mathrm{DM}, 230 \mathrm{~g}$ $\mathrm{kg}^{-1} \mathrm{CP}, 780 \mathrm{~g} \mathrm{~kg}^{-1} \mathrm{TDN}$ and $2.839 \mathrm{Mcal} \mathrm{kg}^{-1}$ of ME. The sheep were sent to the pasture at $8 \mathrm{~h} 00$ and were housed at $16 \mathrm{~h} 00$, where they received the concentrate individually in the trough daily. The pasture composition is presented in Table 1. Further details are to be found in Brito et al. (2013).

The forage was harvested weekly in the paddocks at the entrance and exit of the animals aiming to estimate the availability of the forage mass (Table 1). In each paddock, four representative samples were collected at a height of approximately $5 \mathrm{~cm}$ from the ground in 0.5 $\times 1.0 \mathrm{~m}$ rectangles and together formed a composite sample. This sample was weighed and represented the weight of forage available in $2 \mathrm{~m}^{2}$ and was used to calculate the availability in one hectare. For chemical analysis (Table 1) of forage, another sample was collected from each paddock immediately before the animal entrance by simulating grazing. The simulating grazing was done after careful observation of the area and trying to capture samples by hand that closely represent the one ingested by animal grazing (Sollenberger and Cherney, 1995). The neutral and acid detergent fiber content were analyzed according to Van Soest et al. (1991), and the dry matter, crude protein, ether extract, inorganic phosphorus and mineral matter according to Silva and Queiroz (2002). Moreover, total digestible nutrients (TDN) was calculated according to Cappelle et al. (2001) using the equation $\mathrm{TDN}=9.6086-0.669233 \mathrm{NDF}+0.437932$ $\mathrm{CP}(\mathrm{R} 2=0.71)$.

The animals were dewormed before the begining of the study, using the Albendazole and Levamizole combination.

Dry matter intake was estimated 84 days after the beginning of the experiment by an external indicator technique using purified and enriched lignin capsule (LIPE ${ }^{\circledR} 250 \mathrm{mg} \mathrm{d}^{-1}$ ), given orally to the lambs with the aid of a probang tube, for five consecutive days. The fecal samples were collected for four days, stored together and formed a composite sample, making a total of 30 samples, one from each lamb, which were frozen at $-20{ }^{\circ} \mathrm{C}$ for subsequent analysis. The determination of this indicator in feces was done by infrared spectroscopy. After predrying the feces (in an oven with forced air ventilation at $60-65^{\circ} \mathrm{C}$ ) they were ground in a Wiley mill through a sieve with a $1 \mathrm{~mm}$ mesh size and dry matter content (DM) was determined at $105^{\circ} \mathrm{C}$ (AOAC, 2005).

When the lambs were weighed weekly, the following measures were taken including initial weight (IW), weekly weight (WW), final weight (FW), live weight gain (LWG) and average daily gain (ADG). Moreover, dry matter intake from pasture (DMI pasture $)$, dry matter intake of crude protein $\left(\mathrm{DMI}_{\mathrm{CP}}\right)$, total dry matter intake $\left(\mathrm{DMI}_{\text {total }}\right)$, dry matter intake in relation to total carcass weight at slaughter $\left(\mathrm{DMI}_{\% \mathrm{cw}}\right)$; metabolic weight (MW) and dry matter intake per $\mathrm{kg}$ of metabolic weight $\left(\mathrm{DMI}_{0.75}\right)$ were also estimated.

Table 1 - Chemical analysis of forage of different grazing systems ( $\mathrm{g} \mathrm{kg}^{-1}$ dry matter).

\begin{tabular}{|c|c|c|c|c|c|}
\hline \multirow{2}{*}{ Items } & \multicolumn{3}{|c|}{ Grazing Systems } & \multirow{2}{*}{ CV } & \multirow{2}{*}{$\operatorname{Pr}>\mathrm{F}$} \\
\hline & Simultaneous & Alternate & Isolated & & \\
\hline & & & & $\%$ & \\
\hline Forage (kg ha-1) & 3200 & 3176 & 3672 & 15.26 & 0.3858 \\
\hline Leaf portion & $616^{a}$ & $516^{b}$ & $572^{\mathrm{ab}}$ & 13.83 & 0.0398 \\
\hline Stem portion & 255 & 298 & 286 & 12.64 & 0.5712 \\
\hline Leaf:stem ratio & $2.75^{\mathrm{a}}$ & $1.90^{\mathrm{b}}$ & $2.23^{\mathrm{ab}}$ & 19.68 & 0.0198 \\
\hline Dry matter & 229 & 249 & 230 & 6.89 & 0.6279 \\
\hline Crude protein & $158^{a}$ & $120^{\mathrm{b}}$ & $151^{\mathrm{a}}$ & 8.32 & 0.0321 \\
\hline Neutral detergent fiber & $670^{b}$ & $703^{a}$ & $671^{\text {b }}$ & 9.80 & 0.0453 \\
\hline Acid detergent fiber & $372^{\mathrm{ab}}$ & $392^{\mathrm{a}}$ & $368^{b}$ & 6.88 & 0.0167 \\
\hline Ether extract & 26 & 24 & 25 & 3.10 & 0.9245 \\
\hline Mineral matter & 89 & 87 & 85 & 3.80 & 0.2287 \\
\hline Inorganic phosphorus & 2.7 & 2.5 & 2.5 & 27.57 & 0.952 \\
\hline Total nutrients digestive & $536^{a}$ & $498^{b}$ & $533^{a}$ & 4.66 & 0.0402 \\
\hline
\end{tabular}

$\overline{\mathrm{CV}}=$ coefficient of variation. Means within the same line with different superscript letters are significantly different $(p<0.05)$ using the Tukey test. 
After 99 days of experimentation, the lambs were sent for slaughter in an abattoir accredited by the Brazilian Federal Inspection System after being fasted for 24 hours then weighed after slaughter to obtain total carcass weight at slaughter and also body condition assessment based on a scale of 1 to 5 .

The body score was evaluated subjectively by the amount and distribution of external fat on the carcass in increments, ranging from one (thin) to five (very fat) on a 0.25 interval scale. Moreover, the external carcass length (distance between the base of the tail and the neck base), leg and scrotum circumference were measured with a metric tape.

After bleeding, skin thickness at the navel was measured and then removed and weighed. In addition, the thoracic (lung, heart and trachea), and abdominal cavity (liver, kidneys) viscerae were weighed. After evisceration the carcass was weighed to determine the hot carcass weight. Hot carcass yield (HCY) was calculated as follows: $\mathrm{HCY}=\mathrm{HCW} / \mathrm{CW} \times 100$ then this carcass was stored in a freezer at $4{ }^{\circ} \mathrm{C}$ and weighed after 24 hours to obtain both cold carcass weight and cold carcass yield $(\mathrm{CCY})$ and was calculated as: $\mathrm{CCY}=\mathrm{CCW} / \mathrm{CW} \times 100$, where HCW is the hot carcass weight, CCW the cold carcass weight and CW the carcass slaughter weight.

Cooling weight loss (CWL), which constitutes the loss of carcass humidity in cold storage and chemical reactions in the muscle during the cooling process, was measured as: $\mathrm{CWL}=(\mathrm{HCW}-\mathrm{CCW}) / \mathrm{HCW}) \times 100$, where HCW is the hot carcass weight and CCW the cold carcass weight.

The carcass was separated into two equal portions with a longitudinal section along the spine. The two halves of carcass were weighed and each was divided into five commercial cuts according to Santos et al. (2008). These cuts were leg, shoulder, loin, rib/flank and neck which were weighed separately. However, the percentage of each cut was calculated by dividing each cut weight by the cold carcass weight of the half of carcass. Furthermore, carcass yield (Killout) was calculated by dividing cold carcass weight (CCW) by carcass slaughter weight $(\mathrm{CW})($ Killout $=\mathrm{CCW} / \mathrm{CW})$.

The eye muscle area (EMA) was determined in the cross section of the Longissimus lumborum muscle of the 12th intercostal space, using the checkered transparent standard (Calnan et al., 2014).

The $12^{\text {th }}$ rib was removed from the left half of carcass by a cut made on the cranial face of the $12^{\text {th }}$ and $13^{\text {th }}$ ribs and was packed in plastic bags, identified and stored at $-20{ }^{\circ} \mathrm{C}$ for subsequent analysis, and was then weighed. Next muscle, bone and fat were separated by scalpel and weighed separately. From the weights of these tissues the following relations were estimated: muscle: bone; muscle: fat and comestible portion (equivalent to the percentage of the sum of muscle and fat relative to the total weight), where comestible portion $(\%)=($ muscle weight + fat weight $) \times 100 /$ total weight of $12^{\text {th }}$ rib.
After weighing, the tissues of the rib components were milled together, and dried in an oven at $100{ }^{\circ} \mathrm{C}$ to constant weight. All the materials were analysed for crude protein, ether extract, dry matter and mineral matter according to AOAC (2005).

All data were analyzed by Statistical Analysis System (SAS ${ }^{\circledR}$ Institute, Cary, NC, USA, version 9.3) using a general linear model (GLM) procedure. The means were compared by Tukey test, and $p \leq 0.05$ was considered statistically significant. The statistical model used was $\mathrm{Yij}=\mu+\mathrm{Si}+$ eij $(\mathrm{Yij}=$ individual observation, $\mu=$ overall mean, $\mathrm{Si}=$ grazing systems $(\mathrm{i}=\mathrm{S}, \mathrm{A}, \mathrm{I})$ and eij $=$ experimental error.

\section{Results and Discussion}

Evaluation of the dry matter intake of ruminants at pasture has been a great challenge to researchers, due to the difficulty of obtaining accurate estimates of feed intake but this is important when comparing different grazing systems. The dry matter intake estimated through an external indicator technique using purified and enriched lignin capsule was similar under the different grazing systems (Table 2).

Cordova et al. (1978) noted that evaluation of dry matter intake, when expressed as an absolute number, is not appropriate because of the difficulty in comparing experiments with variation in live weight among animals. Generally, an increase in consumption leads to an increase in live weight, suggesting that it is more convenient to express consumption as a function of live weight. In this case it was observed that the average consumption of sheep under different treatments was $2 \% \mathrm{CW}$ (carcass slaughter weight), being slightly below the $3 \%$ for a $20 \mathrm{~kg}$ lamb suggested by McDonald et al. (2002). Moreover, consumption is directly correlated with forage quality, especially NDF and ADF contents, which are generally higher for tropical grasses as in the case of Tanzania, which may have caused lower intake in relation to temperate grasses.

In response to the different systems of pasture management the quality of Tanzania grass during this experiment was not similar (Santos et al., 2011). According

Table 2 - Average of dry matter intake (DMI) for sheep in different grazing systems, through an external indicator technique using purified and enriched lignin capsule marker.

\begin{tabular}{|c|c|c|c|c|c|}
\hline \multirow{2}{*}{ Items } & \multicolumn{3}{|c|}{ Grazing Systems } & \multirow{2}{*}{ CV } & \multirow{2}{*}{$\operatorname{Pr}>\mathrm{F}$} \\
\hline & Simultaneous & Alternate & Isolated & & \\
\hline & & & & $\%$ & \\
\hline $\mathrm{DMI}_{\text {total }}(\mathrm{kg})$ & 0.725 & 0.779 & 0.898 & 12.00 & 0.1213 \\
\hline $\mathrm{DMl}_{\text {pasture }}(\mathrm{kg})$ & 0.549 & 0.603 & 0.722 & 15.55 & 0.4933 \\
\hline $\mathrm{DMl}_{\mathrm{CP}}(\mathrm{kg})$ & 0.135 & 0.133 & 0.143 & 21.74 & 0.4170 \\
\hline $\mathrm{DMI}_{\% \mathrm{CW}}(\%)$ & 2.22 & 2.37 & 2.64 & 13.51 & 0.3164 \\
\hline $\mathrm{DM}^{0.75}\left({ }^{-1} 0.75 \mathrm{~kg}\right)$ & 52.98 & 56.73 & 63.73 & 18.18 & 0.2494 \\
\hline
\end{tabular}

$\mathrm{CV}=$ coefficient of variation; $\mathrm{CP}=$ crude protein, $\% \mathrm{CW}=$ total carcass weight at slaughter; $\mathrm{MW}^{0.75}=$ metabolic weight. 
Table 3 - Least square means of initial weight, final weight, live weight gain (LWG) and average daily gain (ADG), of sheep obtained during the trial period.

\begin{tabular}{|c|c|c|c|c|c|}
\hline \multirow{2}{*}{ Items } & \multicolumn{3}{|c|}{ Grazing Systems } & \multirow{2}{*}{ CV } & \multirow{2}{*}{$\operatorname{Pr}>\mathrm{F}$} \\
\hline & Simultaneous & Alternate & Isolated & & \\
\hline & & & & $\%$ & \\
\hline Initial weight (kg) & 21.98 & 23.44 & 22.68 & 9.79 & 0.4243 \\
\hline Final weight (kg) & 35.64 & 34.94 & 35.90 & 8.53 & 0.4264 \\
\hline LWG (kg) & $13.66^{\mathrm{a}}$ & $11.50^{\mathrm{b}}$ & $13.19^{a b}$ & 16.04 & 0.0485 \\
\hline ADG $\left(\mathrm{kg} \mathrm{head}^{-1} \mathrm{~d}^{-1}\right)$ & $0.145^{\mathrm{a}}$ & $0.122^{\mathrm{b}}$ & $0.140^{\mathrm{ab}}$ & 16.04 & 0.0379 \\
\hline
\end{tabular}

to Santos et al. (2011) simultaneous and isolated systems presented better quality of grass than the alternate. The leaf:stem ratio, protein content, neutral detergent fiber content and total digestible nutrients in the simultaneous system, resulted in better performance of sheep in the simultaneous system compared to the alternate system (Table 3). It was evident that the better pasture quality in the simultaneous system provided greater weight gain for the sheep, with a possible increase in the digestibility of forage and greater concentration of nutrients from the diet guaranteeing better animal performance (Hodgson, 1990). In the simultaneous grazing system, the animals had higher live weight gains than under the alternate system, while the isolated system showed intermediate results, which was no different from the others. The lamb weight gain in both simultaneous 10.145 $\mathrm{kg}$ per head per day) and isolated $(0.140 \mathrm{~kg}$ per head per day) systems were higher than that found by Silva et al. (2007) which was $0.123 \mathrm{~kg}$ per head per day in Tanzania pasture without concentrate supplementation which was close to the alternate $(0.122 \mathrm{~kg}$ per head per day) with concentrate supplementation.

Under the simultaneous and isolated systems there was better forage utilization, as the same dry matter production and the forage available for the animals was richer in leaves, where most digestible nutrients are concentrated. This difference can be explained by the fact that under the simultaneous and isolated systems, the instantaneous stocking rate was higher during the period of occupation, since all the animals allocated to their respective grazing systems consumed the available forage in one week while under the alternate system the same paddock was occupied for 14 consecutive days, and 7 days for each of the cattle and sheep categories, which have different grazing habits. Under the alternate system, cattle had already passed through the paddock before sheep had access. Thus, most of the leaves had been consumed leaving the sheep a lower quality forage. In this study, the option of cattle grazing prior to sheep was selected due to the fact that cattle may eat tip larvae thereby reducing the grass parasite load. Infective larvae of sheep parasites are destroyed when ingested by cattle (Amarante et al., 1997; Torres et al., 2009).
According to Nolan and Connolly (1977), who studied the effect of mixed exploration of cattle and sheep on variables of the plant animal interface, concluded that this type of exploration increases the production per area and per animal compared to the use of forage with only one species. This effect is related to three consequences of this exploration: increased pasture production, improved forage quality and use efficiency (Nolan and Connolly, 1989). Furthermore Baker (1985) and Nolan and Connolly (1989), stated that the origin of this positive effect would be the complementary grazing patterns associated with the different preferences of each animal species for different plants, plant parts or geographical locations. In this same study, Santos et al. (2011), observed the preference for plant parts and geographical location.

There was no significant difference between different grazing systems for sheep carcass traits, body components and commercial cuts (Tables 4 and 5).

The yield average for the hot carcass obtained in the present study was close to that found by Cardoso et al. (2013) in Santa Ines sheep (47 \%) slaughtered between 30 and $45 \mathrm{~kg} \mathrm{CW}$. These results were close to the lower limit of the normal range for this parameter which ranged from 45 to $60 \%$ depending on various factors such as genetics, gender, age, body weight, birth weight, fasting time and diet effect on animals (Petit et al., 1997; Fimbres et al., 2002).

Cooling losses were the same in lambs from different grazing systems averaging $5 \%$. However, previous studies state that these losses range from 1 to $7 \%$ depending on the uniformity of fat cover, sex, weight, temperature and relative humidity of the storage room (Lan-

Table 4 - Least square means of carcass characteristics and body components of sheep reared in different grazing systems.

\begin{tabular}{|c|c|c|c|c|c|}
\hline \multirow{2}{*}{ Items } & \multicolumn{3}{|c|}{ Grazing Systems } & \multirow{2}{*}{ CV } & \multirow{2}{*}{$\operatorname{Pr}>\mathrm{F}$} \\
\hline & \multirow[t]{2}{*}{ Simultaneous } & \multicolumn{2}{|c|}{ Alternate Isolated } & & \\
\hline & & & & $\%$ & \\
\hline Live weight (kg) & 34.25 & 34.30 & 34.56 & 8.12 & 0.9684 \\
\hline $\mathrm{ECL}(\mathrm{cm})$ & 73.35 & 75.30 & 73.61 & 3.99 & 0.2977 \\
\hline Hot carcass weight (kg) & 15.67 & 15.31 & 15.82 & 10.27 & 0.7732 \\
\hline CCW (kg) & 15.25 & 15.00 & 15.20 & 11.06 & 0.9409 \\
\hline $\mathrm{HCY}(\%)$ & 46 & 45 & 46 & 5.57 & 0.4966 \\
\hline $\operatorname{CCY}(\%)$ & 44 & 44 & 44 & 5.08 & 0.8121 \\
\hline WLC (\%) & 5 & 4 & 5 & 62.11 & 0.9416 \\
\hline DF (1-5) & 2.53 & 2.33 & 2.47 & 17.44 & 0.6146 \\
\hline SW (kg) & 2.60 & 2.50 & 2.50 & 10.67 & 0.6436 \\
\hline ST (mm) & 3.72 & 3.51 & 3.42 & 20.67 & 0.6629 \\
\hline WTO (kg) & 1.00 & 1.05 & 1.00 & 9.14 & 0.4011 \\
\hline WAO (kg) & 0.90 & 0.95 & 0.89 & 21.61 & 0.7700 \\
\hline $\mathrm{SC}(\mathrm{cm})$ & 28.50 & 28.75 & 28.89 & 7.80 & 0.9287 \\
\hline $\mathrm{LC}(\mathrm{cm})$ & 36.15 & 36.72 & 35.06 & 7.94 & 0.4633 \\
\hline
\end{tabular}


Table 5 - Least square means of weights and yields of commercial cuts of sheep reared in different grazing systems.

\begin{tabular}{|c|c|c|c|c|c|}
\hline \multirow{2}{*}{ Items } & \multicolumn{3}{|c|}{ Grazing System } & \multirow{2}{*}{ CV } & \multirow{2}{*}{$\operatorname{Pr}>\mathrm{F}$} \\
\hline & \multicolumn{3}{|c|}{ Simultaneous Alternate Isolated } & & \\
\hline \multirow{2}{*}{\multicolumn{6}{|c|}{ Carcass cut weights (kg) }} \\
\hline & & & & & \\
\hline Half cold carcass & 7.71 & 7.48 & 7.77 & 10.39 & 0.6988 \\
\hline Leg & 2.43 & 2.29 & 2.43 & 10.76 & 0.3567 \\
\hline Shoulder & 1.38 & 1.45 & 1.51 & 12.10 & 0.3084 \\
\hline Neck & 0.49 & 0.55 & 0.55 & 21.52 & 0.3565 \\
\hline Loin & 0.55 & 0.60 & 0.58 & 24.35 & 0.7209 \\
\hline Rib/flank & 2.60 & 2.33 & 2.59 & 15.72 & 0.2451 \\
\hline \multicolumn{6}{|l|}{ Cut yields (\%) } \\
\hline Leg & 32 & 31 & 31 & 12.15 & 0.4746 \\
\hline Shoulder & 18 & 19 & 19 & 10.35 & 0.2798 \\
\hline Neck & 6 & 7 & 7 & 18.21 & 0.2545 \\
\hline Loin & 7 & 8 & 7 & 20.91 & 0.4502 \\
\hline Rib/flank & 33 & 31 & 33 & 10.23 & 0.2744 \\
\hline
\end{tabular}

dim et al., 2011; Cardoso et al., 2013). Furthermore, the sheep carcasses recorded an intermediate fatness score (Russo et al., 2003) due to the degree of fat found which ranged between 2.33 and 2.53 which is consistent with the standard range for Santa Ines sheep which present less fat cover than wool sheep as specialized meat breeds that may facilitate the loss of water during cooling process. On the other hand, the other carcass traits, body components and commercial cuts were within normal variations of slaughtered Santa Ines sheep weighing 30 kg (Cardoso et al., 2013).

The results pertaining to the measurements of eye muscle area (Table 6) were close to those observed by Landim et al. (2011) and Cardoso et al. (2013). Moreover, this muscle has a late maturity, and is the most suitable for representing the development and size of muscle tissue (Rahman, 2007), as the greater the accumulation of fat, the lower the proportion of muscles (Forrest et al., 1975).

The ether extract percentage in the Longissimus lumborum muscle is an important indicator of the percentage of intramuscular carcass fat (Monteiro et al., 2006). In this study, the ether extract percentage mean value observed was $12 \%$. The parameters of humidity, protein and mineral matter of eye muscle in this study were lower than those found by Liu et al. (2015) working with Oula lamb slaughter with different live weight.

With regard to the bone and muscle:bone ratio percentage, they were affected by different grazing systems in that the alternate system showed less bone percentage and higher muscle:bone ratio. Moreover, this relationship has great commercial interest since it is directly related to the edible portion and, therefore, the higher the ratio, the greater the benefit to the consumer. However, this relationship should be analyzed with caution.
Table 6 - Least square means of eye muscle area measurements and chemical composition of $12^{\text {th }}$ rib tissue of sheep reared in different grazing systems.

\begin{tabular}{|c|c|c|c|c|c|}
\hline \multirow{2}{*}{ Items } & \multicolumn{3}{|c|}{ Grazing Systems } & \multirow{2}{*}{ CV } & \multirow{2}{*}{$\mathrm{Pr}>\mathrm{F}$} \\
\hline & Simultaneous & Alternate & Isolated & & \\
\hline & & & & $\%$ & \\
\hline \multicolumn{6}{|c|}{ Area, weight and percentage } \\
\hline EMA $\left(\mathrm{cm}^{2}\right)$ & 12.92 & 12.77 & 12.08 & 16.56 & 0.6586 \\
\hline Weight (g) & 87.19 & 82.74 & 93.95 & 18.03 & 0.3176 \\
\hline Muscle (g) & 66.12 & 62.93 & 66.04 & 17.93 & 0.3567 \\
\hline Muscle (\%) & 73 & 76 & 72 & 6.56 & 0.2359 \\
\hline Bone (g) & 9ab & $7^{b}$ & $9^{a}$ & 23.44 & 0.0460 \\
\hline Bone (\%) & 10 & 9 & 10 & 17.23 & 0.1591 \\
\hline Fat (g) & 14.95 & 12.64 & 16.05 & 36.76 & 0.555 \\
\hline Fat (\%) & 17 & 15 & 18 & 28.47 & 0.5339 \\
\hline \multicolumn{6}{|c|}{ Ratio } \\
\hline muscle:bone (\%) & $7^{\mathrm{b}}$ & $9^{a}$ & $8^{b}$ & 20.23 & 0.0530 \\
\hline muscle:fat (\%) & 5 & 6 & 4 & 50.97 & 0.1474 \\
\hline Edibe portion (\%) & 90 & 91 & 90 & 1.81 & 0.1591 \\
\hline \multicolumn{6}{|c|}{ Chemical composition } \\
\hline Humidity (\%) & 63 & 62 & 63 & 5.67 & 0.6680 \\
\hline Dry matter (\%) & 37 & 38 & 37 & 9.55 & 0.6680 \\
\hline Protein (\%) & 20 & 20 & 19 & 6.03 & 0.1008 \\
\hline Ether extract (\%) & 11 & 12 & 13 & 34.99 & 0.3579 \\
\hline Mineral matter (\%) & 5 & 5 & 4 & 14.23 & 0.6030 \\
\hline
\end{tabular}

\section{Conclusions}

The different grazing systems did not affect the quantitative carcass traits nor the dry matter intake of sheep. However, the choice of the most appropriate grazing system results in the best forage production and animal performance, which was observed under the simultaneous grazing system of sheep and cattle and the isolated system of sheep only.

\section{Acknowledgments}

Thanks are due to the Foundation for Research Support of the Distrito Federal (FAPDF) for financing and the Coordination for the Improvement of Higher Level Personnel (CAPES) and the Brazilian National Council for Scientific and Technological Development (CNPq) for scholarships.

\section{References}

Alvares, C.A.; Stape, J.L.; Sentelhas, P.C.; Gonçalves, J.L.M; Sparovek, G . 2013. Köppen's climate classification map for Brazil. Meteorologische Zeitschrift 22: 711-728.

Amarante, A.F.T.; Bagnola Júnior, J.; Amarante, M.R.V.; Barbosa, M.A. 1997. Host specificity of sheep and cattle nematodes in São Paulo state, Brazil. Veterinary Parasitology 73: 89-104.

Association of Official Analytical Chemists [AOAC]. 2005. Official Methods of Analysis. 18ed. AOAC, Gaithersburg, MD, USA. 
Bailey, J.N.; Walkden-Brown, S.W.; Kahn L.P. 2009. Comparison of strategies to provide lambing paddocks of low gastro-intestinal nematode infectivity in a summer rainfall region of Australia. Veterinary Parasitology 161: 218-231.

Baker, F.H. 1985. Multispecies grazing: the state of the science. Rangelands 7: 266-269.

Blanco, C.; Sosinski, E.; Santos, B.; Silva, M.A, Pillar, V.P. 2007. On the overlap between effect and response plant functional types linked to grazing. Community Ecology 8: 57-65.

Brito, D.L.; Dallago, B.S.L.; Louvandini, H.; Santos, V.R.V.; Torres, S.E.F.A.; Gomes, E.F.; Amarante, A.F.T.; Melo, C.B.; McManus, C.M. 2013. Effect of alternate and simultaneous grazing on endoparasite infection in sheep and cattle. Brazilian Journal of Veterinary Parasitology 22: 485-494.

Calnan, H.B.; Jacob, R.H.; Pethick, D.W.; Gardner, G.E. 2014. Factors affecting the colour of lamb meat from the longissimus muscle during display: the influence of muscle weight and muscle oxidative capacity. Meat Science 96: 1049-1057.

Cappelle, E.R; Valadares Filho, S.C.; Silva, J.F.C; Cecon, P.R. 2001. Estimates of the energy value from chemical characteristics of the feedstuffs. Revista Brasileira de Zootecnia 30: 1837-1856 (in Portuguese, with abstract in English).

Cardoso, M.T.M.; Landim, A.V.; Louvandini, H.; McManus, C. 2013. Performance and carcass quality in three genetic groups of sheep in Brazil. Brazilian Journal of Animal Science 42: 734742.

Cordova, F.J.; Wallace, J.D.; Pieper, R.D. 1978. Forage intake by grazing livestock: a review. Journal of Range Management 31: 430-438.

Dickhoefer, U.; Hao, J.; Bösing, B.M.; Lin, L.; Gierus, M.; Taube, F.; Susenbeth, A. 2014. Feed intake and performance of sheep grazing semiarid grassland in response to different grazing systems. Rangeland Ecology and Management 67: 145-153.

Fimbres, H.; Hernández-Vidal, G.; Picón-Rubio, J.F.; Kawas, J.R.; Lu, C.D. 2002. Productive performance and carcass characteristics of lambs fed finishing ration containing various forage levels. Small Ruminant Research 43: 283-288.

Forbes, T.D.A.; Hodgson, J. 1985. The reaction of grazing sheep and cattle to the presence of dung from the same or the other species. Grassland and Forage Science 40: 177-182.

Forrest, J.C.A.; Aberle, E.D.A.; Hedrick, H.B.; Judge, M.D.; Merkel, R.A. 1975. Principles of Meat Science. W.H. Freeman, San Francisco, CA, USA.

Hodgson, J. 1990. Grazing management: science into practice. Longman, London, UK.

Jerrentrup, J.S.; Seither, M.; Petersen, U.; Isselstein, J. 2015. Little grazer species effect on the vegetation in a rotational grazing system. Agriculture, Ecosystems and Environment 202: 243250.

Landim, A.V.; Fioravanti, M.C.S.; Cardoso, M.T.M.; Louvandini, H.; Castanheira, M.; Pacheco, A.L.; McManus, C. 2011. Physical, chemical and sensorial parameters for lambs of different groups, slaughtered at different weights. Tropical Animal Health and Production 43: 1089-1096.

Liu, J-b.; Guo, J.; Wang, F.; Yue, Y-j.; Zhang, W-1.; Feng, R-1.; Guo, T-t.; Yang, B-h.; Sun, X-p. 2015. Carcass and meat quality characteristics of Oula lambs in China. Small Ruminant Research 123: 251-259.
McClure, K.E.; Solomon, M.G.; Parret, N.A.; Van Keuren, R.W. 1995. Growth and tissue accretion of lambs fed concentrate in drylot, grazed on alfalfa or ryegrass at weaning, or after backgrounding on ryegrass. Journal of Animal Science 73: 3437-3444.

McDonald, P.; Edwards, R.A.; Greenhalgh, J.F.D.; Morgan, C.A. 2002. Animal Nutrition. Longman, London, UK.

Monteiro, A.C.G.; Santos-Silva, J.; Bessa, R.J.B.; Navas, D.R.; Lemos, J.P.C. 2006. Fatty acid composition of intramuscular fat of bulls and steers. Livestock Science 99: 13-19.

Nolan, T.; Connolly J. 1989. Mixed v. mono-grazing by steers and sheep. Animal Production 48: 519-533.

Nolan, T.; Connolly, J. 1977. Mixed stocking by sheep and steers: a review. Herbage Abstracts 47: 367-374.

Petit, H.V.; Tremblay, G.F.; Savoie, P. 1997. Performance of growing lambs fed two levels of concentrate with conventional or macerated timothy hay. Journal of Animal Science 75: 598603.

Priolo, A.; Micol, D.; Agabiel, J.; Prache, S.; Dransfield, E. 2002. Effect of grass or concentrate feeding on lamb carcass and meat quality. Meat Science 62: 179-185.

Rahman, M.F. 2007. Estimation of relationship between hot carcass weight and eye muscle area which effects on meat production of black bengal goats. Pakistan Journal of Nutrition 6: 33-34.

Rook, A.; Dumont, B.; Isselstein, J.; Osoro, K.; Wallis DeVries, M.; Parente, G.; Mills, J. 2004. Matching type of livestock to desired biodiversity outcomes in pastures: a review. Biological Conservation 119: 137-150.

Russo, C.; Prezuiso, G.; Veritá, P. 2003. EU carcass classification system: carcass and meat quality in light lambs. Meat Science 64: 411-416.

Rutter, S.M. 2010. Grazing preferences in sheep and cattle: implications for production, the environment and animal welfare. Canadian Journal of Animal Science 90: 285-293.

Saggar, S.; Giltrap, D.L.; Davison, R.; Gibson, R.; Klein, C.A.M.; Rollo, M.; Ettema, P.; Rys, G. 2015. Estimating direct $\mathrm{N}_{2} \mathrm{O}$ emissions from sheep, beef, and deer grazed pastures in New Zealand hill country: accounting for the effect of land slope on the $\mathrm{N}_{2} \mathrm{O}$ emission factors from urine and dung. Agriculture, Ecosystems and Environment 205: 70-78.

Santos, V.A.C.; Silva, S.R.; Azevedo, J.M.T. 2008. Carcass composition and meat quality of equally mature kids and lambs. Journal of Animal Science 86: 1943-1950.

Santos, V.R.V.; Louvandini, H.; Pimentel, C.M.M.; Brito, D.L. 2011.Structural and chemical traits of tanzania grass under isolated, simultaneous and alternated grazing by sheep and cattle. Ciência Animal Brasileira 12: 670-680 (in Portuguese with abstract in English).

Silva, A.M.A.; Silva Sobrinho, A.G.; Trindade, I.A.C.M.; Resende, K.T.; Bakke, O.A. 2007. Net and metabolizable protein requirements for body weight gain in hair and wool lambs. Small Ruminant Research 67: 192-198.

Silva, D.J. ; Queiroz, A.C. 2002. Food Analysis: Chemical and Biological Methods. = Análise de Alimentos: Métodos Químicos e Biológicos. Editora da UFV, Viçosa, MG, BR (in Portuguese). 
Sollenberger, L.E.; Cherney, D.J.R. 1995. Evaluating forage production and quality. v. 2, p. 97-110. In: Barnes, R.F; Miller, D.A.; Nelson, C.J., eds. Forages: the science of grassland agriculture. Iowa State University Press, Ames, IA, USA.

Torres, S.E.F.; McManus C.; Amarante, A.F.T.; Verdolin, V.; Louvandini, H. 2009. Ruminant nematodes in pasture under different grazing systems with sheep and cattle. Pesquisa Agropecuária Brasileira 44: 1191-1197 (in Portuguese, with abstract in English).
Van Soest, P.J.; Robertson, J.B.; Lewis, B.A. 1991. Methods for dietary fiber, neutral detergent fiber, and nonstarch polysaccharides in relation to animal nutrition. Journal of Dairy Science 74: 3583-3597.

Wrage, N.; Strodthoff, J.; Cuchillo, H.M.; Isselstein, J.; Kayser, M. 2011. Phytodiversity of temperate permanent grasslands: ecosystem services for agriculture and livestock management for diversity conservation. Biodiversity Conservation 20: 33173339. 